\title{
MASYARAKAT SUNGAI BABALAN: SEJARAH SOSIAL DESA PERLIS, PANGKALAN BRANDAN (1940-2004)
}

\author{
Septiansyah Tanjung1, Rosmaida Sinaga ${ }^{2}$ \\ 1) Alumni Jurusan Pendidikan Sejarah, Universitas Negeri Medan, Indonesia \\ 2) Jurusan Pendidikan Sejarah, Universitas Negeri Medan, Indonesia \\ Corresponding Email: septiansyahtanjung15@gmail.com
}

\begin{abstract}
This article discusses the social history of the Perlis Village community, Pangkalan Brandan in 1940-2004. The research method used is the historical method by utilizing written sources, such as travel reports, books, journals and maps. Oral information from locals and artifacts was also used as a source of writing. This study uses a social history approach that places society as the main study. The approach to social history is supported by the use of theories and concepts of social and cultural sciences. This study shows that Perlis was formed by various ethnic groups with the dominant role of immigrants from Perlis country, Malaya Peninsula, at the beginning of the formation of the community. The Malay ethnic community becomes the majority in Perlis with a livelihood as fishermen. The entry of Chinese in 1940, then followed by Javanese and Acehnese in 1960 added to the type of livelihood in Perlis. Population growth affects various economic sectors, from fisheries, livestock to agriculture. Perlis village is known for its various natural products, from fish, poultry to rice. Major changes occurred in 1990 to the beginning of 2000. The ethnic Chinese population urbanized and the paddy fields turned into oil palm plantations. This has an impact on the changing culture and traditions that are run by the residents of Perlis.
\end{abstract}

Keywords: Pangkalan Brandan, Perlis Village, Social History

\begin{abstract}
Abstrak
Artikel ini membahas tentang sejarah sosial masyarakat Desa Perlis, Pangkalan Brandan pada tahun 19402004. Metode penelitian yang digunakan adalah metode sejarah dengan memanfaatkan sumber-sumber tertulis, seperti laporan perjalanan, buku, jurnal dan peta. Keterangan lisan dari penduduk setempat dan artefak juga digunakan sebagai sumber penulisan. Kajian ini menggunakan pendekatan sejarah sosial yang menempatkan masyarakat sebagai kajian utama. Pendekatan sejarah sosial didukung dengan penggunaan teori dan konsep ilmu-ilmu sosial dan budaya. Kajian ini menunjukkan bahwa Desa Perlis dibentuk oleh beragam etnis dengan peran dominan dari pendatang negeri Perlis, Semenanjung Malaya, diawal pembentukan masyarakatnya. Masyarakat etnis Melayu menjadi mayoritas di Desa Perlis dengan mata pencaharian sebagai nelayan. Masuknya orang Cina pada tahun 1940, kemudian disusul orang Jawa dan Aceh pada tahun 1960 menambah jenis mata pencaharian di Desa Perlis. Pertambahan penduduk berdampak ke sektor perekonomian yang beragam, mulai dari perikanan, peternakan sampai pertanian. Desa Perlis dikenal dengan beragam hasil alamnya, mulai dari ikan, unggas hingga beras. Perubahan besar terjadi pada tahun 1990 hingga awal tahun 2000. Penduduk etnis Cina melakukan urbanisasi dan sawah-sawah beralih menjadi perkebunan kelapa sawit. Hal itu berdampak kepada perubahan budaya dan tradisi yang dijalankan penduduk Desa Perlis.
\end{abstract}

Kata Kunci: Pangkalan Brandan, Desa Perlis, Sejarah Sosial 


\section{PENDAHULUAN}

Pada permulaan abad ke-19, tepatnya tahun 1826, terbit sebuah buku hasil penjelajahan seorang pegawai East India Company di Penang yang bernama John Anderson. Buku tersebut berjudul Mission to the East Coast of Sumatra (Asnan, 2016: 2). Anderson mengunjungi tiaptiap sungai yang terbentang di pantai timur Sumatera, mulai dari Tamiang (Aceh) hingga Siak (Riau). Bukan hanya menginventarisir nama-nama sungai, Anderson juga menghimpun populasi masyarakat, kebudayaan setempat, komoditi hasil bumi, aktivitas perdagangan hingga kegiatan politik.

Salah satu sungai yang dikunjungi oleh Anderson ialah Sungai Babalan. Sungai ini mengalir di wilayah Langkat. Saat ini, aliran sungai tersebut melintasi tiga kecamatan di Kabupaten Langkat, yakni Sei Lepan, Brandan Barat dan Babalan. Sungai tersebut memiliki ekosistem mangrove di muara yang menjadi tempat nelayan setempat menangkap ikan. Anderson menyebut nama sungai ini dalam bukunya dengan penulisan "Sungei Bubalan" (Anderson, 1971: 237). Dari pernyataan singkat Anderson diperoleh informasi bahwa di tepi Sungai Babalan terdapat desa nelayan yang dihuni sekitar 50 orang. Desa nelayan yang berada di Sungai Babalan seperti dikatakan Anderson, diyakini masih ada hingga saat ini. Desa nelayan yang terdapat di sekitar Sungai Babalan berdiri dekat pasar Pangkalan Brandan, yaitu Desa Perlis, Desa Kelantan dan Desa Sei Bilah. Di sisi sungai itu juga berdiri kilang minyak Pangkalan Brandan yang pernah dioperasikan oleh BPM (Bataafsche Petroleum Maatschappij) sejak tahun 1885 sampai 1942, kemudian pengelolaannya diambilalih oleh Pertamina (Perusahaan Pertambangan Minyak dan Gas Bumi Negara) sejak awal kemerdekaan Indonesia hingga kilang itu ditutup pada tanggal 7 Maret 2007 (Daryono, dkk., 2013: 240).

Desa-desa nelayan itu yang mayoritas penduduknya suku Melayu memiliki keunikan, khususnya Desa Perlis yang menjadi kajian penelitian. Desa Perlis terletak di Kecamatan Brandan Barat. Wilayahnya terdiri dari sebuah pulau hasil endapan lumpur yang seolah-olah terpisah dari pulau Sumatera dengan luas 611 ha. Penduduk desa ini mendirikan pemukimannya di pinggir sungai, bahkan ada rumah yang berdiri di atas air dan bagian depannya menghadap langsung ke aliran utama sungai. Penduduk Desa Perlis tidak hanya terdiri dari nelayan saja, tetapi juga petani yang digeluti oleh pendatang Jawa dan peternakan oleh komunitas Cina. Kelompok etnik lain seperti Banjar, Mandailing dan Minangkabau juga membentuk komposisi penduduk desa ini.

Ditinjau secara sosiologis, kehidupan sosial berlangsug dalam wadah yang disebut masyarakat. Dalam konteks pemikiran sistem, masyarakat akan dipandang sebagai sebuah sistem sosial. Satu sistem sosial dapat didefinisikan sebagai suatu pola interaksi sosial yang terdiri dari komponen sosial yang teratur dan melembaga (Narwoko \& Suyanto, 2013: 125). Masyarakat memiliki ketergantungan satu sama lain, yang mengakibatkan sistem itu berjalan. Hal ini tidak terlepas dari sifat manusia sebagai homo socius. Menurut Koentjaraningrat (2009: 116), masyarakat adalah sekumpulan manusia yang saling "bergaul", atau istilah ilmiahnya "saling berinteraksi". Kesatuan manusia yang dapat dikatakan sebagai masyarakat ketika mereka memiliki ikatan. Ikatan dapat dikatakan sebagai suatu pola khas seperti adat istiadat, normanorma dan peraturan-peraturan. Masyarakat yang telah menjadi suatu kesatuan dengan pola yang khas harus mendiami suatu ruang (wilayah) yang menjadi tempat tinggal mereka hingga ruang itu menjadi identitas bersama dengan nilai-nilai sosial dan produk-produk kebudayaan mereka.

Sama halnya dengan masyarakat Desa Perlis yang menjadi satu entitas dengan ciri mata pencahariannya yang mayoritas bekerja sebagai nelayan. Tentu ruang hidup mereka berdekatan dengan kawasan pesisir, seperti sungai, muara dan tepi pantai. Secara geografis, Desa Perlis 
terletak dipinggir Sungai Babalan yang berjarak tidak jauh dari muara sungai. Ada banyak aktivitas di Sungai Babalan, seperti perikanan, perdagangan dan aktivitas pelayaran. Di sisi sungai berdiri pelabuhan kecil milik Pertamina yang difungsikan untuk operasional kilang minyak Pangkalan Brandan. Namun, pelabuhan itu sekarang tak lagi berfungsi maksimal akibat ditutupnya kilang minyak milik Pertamina sejak tahun 2007 (Daryono, dkk., 2013: 240). Berdasarkan realitas tersebut, penduduk Desa Perlis dapat dikatakan sebagai masyarakat sungai. Asnan (2016: 181) menyatakan bahwa masyarakat sungai merupakan masyarakat yang hidup dan kehidupannya amat bergantung pada sungai. Dengan kata lain, sejarah perkembangan masyarakat yang mencakup aktivitas sosial, politik, ekonomi dan budaya berhubungan secara langsung atau tidak langsung dengan sungai.

Kajian ini membahas tentang proses terbentuknya masyarakat Desa Perlis di tepi Sungai Babalan, serta perubahan sosial, ekonomi dan budaya yang mereka alami sepanjang tahun 1940-2004. Masyarakat Desa Perlis dalam kajian ini sesuai dengan konsep masyarakat sungai yang dikemukakan Asnan (2016), karena setiap aspek kehidupan masyarakat Desa Perlis bergantung secara langsung maupun tidak langsung dengan Sungai Babalan.

Penduduk Desa Perlis saat ini berjumlah 5.270 orang dengan 1.518 kepala keluarga. Bila dirinci berdasar jenis kelamin, jumlah penduduk laki-laki sebanyak 2.760 jiwa dan perempuan 2.510 jiwa. Mereka terdiri dari beragam kelompok etnik. Kelompok etnik Melayu mendominasi komposisi masyarakat Desa Perlis dengan jumlah mencapai 3.755 jiwa. Selanjutnya etnik Jawa (436 jiwa), Aceh (332 jiwa), Banjar (240 jiwa), Mandailing (200 jiwa), Minang (170 jiwa), dan 137 jiwa etnis lainnya (BPS Kabupaten Langkat, 2017b, 2017a).

\section{METODE PENELITIAN}

Metode penelitian yang digunakan dalam kajian ini adalah metode sejarah. Kajian ini mencoba merekonstruksi masa lalu masyarakat Desa Perlis berdasarkan fakta yang diperoleh dari hasil kerja metode sejarah. Sebagai sebuah prosedur penelitian, metode sejarah memiliki empat tahapan, yakni heuristik atau pengumpulan sumber, kritik sumber, interpretasi, dan eksplanasi (Sjamsuddin, 2012: 86).

Sumber tertulis yang digunakan adalah buku, artikel jurnal dan laporan perjalanan. Sumber tertulis utama yang digunakan ialah laporan perjalanan John Anderson (Anderson, 1971). Untuk menguatkan data yang diperoleh dari studi pustaka, kajian ini menggunakan sumber lisan yang diperoleh dari wawancara dengan penduduk Desa Perlis. Sumber lain yang digunakan adalah artefak, seperti bangunan, bekas pemukiman dan makam.

Kajian ini menggunakan pendekatan sejarah sosial yang menempatkan masyarakat sebagai kajian utama. Sejarah sosial dapat mengambil fakta-fakta sosial yang terjadi dalam kehidupan sehari-hari masyarakat sebagai bahan kajian, seperti aktivitas ekonomi, kemiskinan, pertumbuhan penduduk, migrasi, interaksi sosial dan kriminalitas. Pendekatan sejarah sosial didukung dengan penggunaan konsep dan teori ilmuilmu bantu, yakni sosiologi dan antropologi.

\section{HASIL DAN PEMBAHASAN Pendirian Desa Perlis}

Sumber tertulis yang menguraikan adanya pemukiman lama di Sungai Babalan hanya didapati dalam laporan perjalanan John Anderson berjudul Mission to the East Coast of Sumatra yang terbit tahun 1826. Pada tahun 1823, East India Company memerintahkan Anderson untuk mengunjungi beberapa "pelabuhan lada" di pantai timur Sumatera. Ia ditugaskan untuk meyakinkan raja-raja di sana mengenai manfaat meneruskan perdagangan bebas dengan Penang (Reid, 2007: 10). Saat melakukan perjalanan, Anderson membuat laporan tertulis tentang kondisi geografi dan kehidupan masyarakat di pantai timur Sumatera. Dalam laporan Anderson terdapat uraian tentang kehidupan masyarakat di 
Sungai Babalan. Menurut Anderson, "di Sungai Babalan terdapat sebuah pemukiman nelayan dengan jumlah penduduk sekitar 50 orang" (Anderson, 1971). Namun, nama dari pemukiman tersebut tidak diuraikan lebih lanjut. Hasil tangkapan para nelayan diperkirakan dijual di pasar-pasar terdekat seperti Pulau Kampai untuk dibarter dengan beras, pakaian, kayu, bahan pangan dan kebutuhan lainnya. Pulau Kampai sendiri sudah sejak lama menjadi salah satu bandar dagang yang penting di pantai timur Sumatera (Koestoro, dkk., 2016: 97).

Pemukiman nelayan di tepi Sungai Babalan diperkirakan berdiri sebelum tahun 1823 . Demikian pula hubungan dagang dengan daerah-daerah sekitarnya sudah terjalin pada saat itu. Pembukaan pemukiman ini berkaitan dengan kehadiran pelarian politik dari Tamiang yang mendirikan pemukiman awal bernama Kampung Tanjung Balai (saat ini bernama Desa Perlis). Penduduk Kampung Tanjung Balai tidak hanya bekerja sebagai nelayan, tetapi juga menjadi pengrajin atap nipah. Produk atap nipah diperdagangkan ke pasar-pasar pelabuhan di pantai timur Sumatera, mulai dari Pulau Kampai hingga ke Tanjung Balai Asahan.

Tokoh yang diyakini sebagai pemimpin kampung tersebut bernama Nyak Aris. Ia aktif terlibat dalam aktivitas perdagangan. Pekerjaan sebagai pedagang yang kerap kali mengunjungi bandar-bandar dagang membuat ia memiliki relasi atau hubungan dengan pedagang-pedagang lain. Apalagi hubungan itu terbentuk disebabkan adanya transaksi jual-beli. Nyak Aris memiliki seorang teman karib yang juga merupakan ulama atau tokoh agama Islam bernama Haji Muhammad Thaif (Haji Mat Thaif) yang berasal dari Negeri Perlis Semenanjung Malaya.

Haji Mat Thaif merupakan pedagang beras dan rempah-rempah. Rempah-rempah yang diperdagangkan olehnya adalah jenis lada yang dibeli dari pelabuhan-pelabuhan di pantai timur Sumatera untuk kemudian dijual lagi di Penang. Lada menjadi komoditi pertanian yang banyak dibudidayakan di pantai timur Sumatera sebelum dibukanya perkebunan tembakau oleh seorang usahawan Belanda yang bernama Nienhuys pada tahun 1863 (Pelzer, 1985: 53). Aktivitas dagang Haji Mat Thaif diperkirakan berlangsung tahun 1830-1860. Dalam kurun waktu yang sama, orang-orang Melayu dari Negeri Perlis (Malaysia) diperkirakan bermigrasi ke Desa Perlis (Wawancara dengan Bapak Muhammad, 17 April 2018).

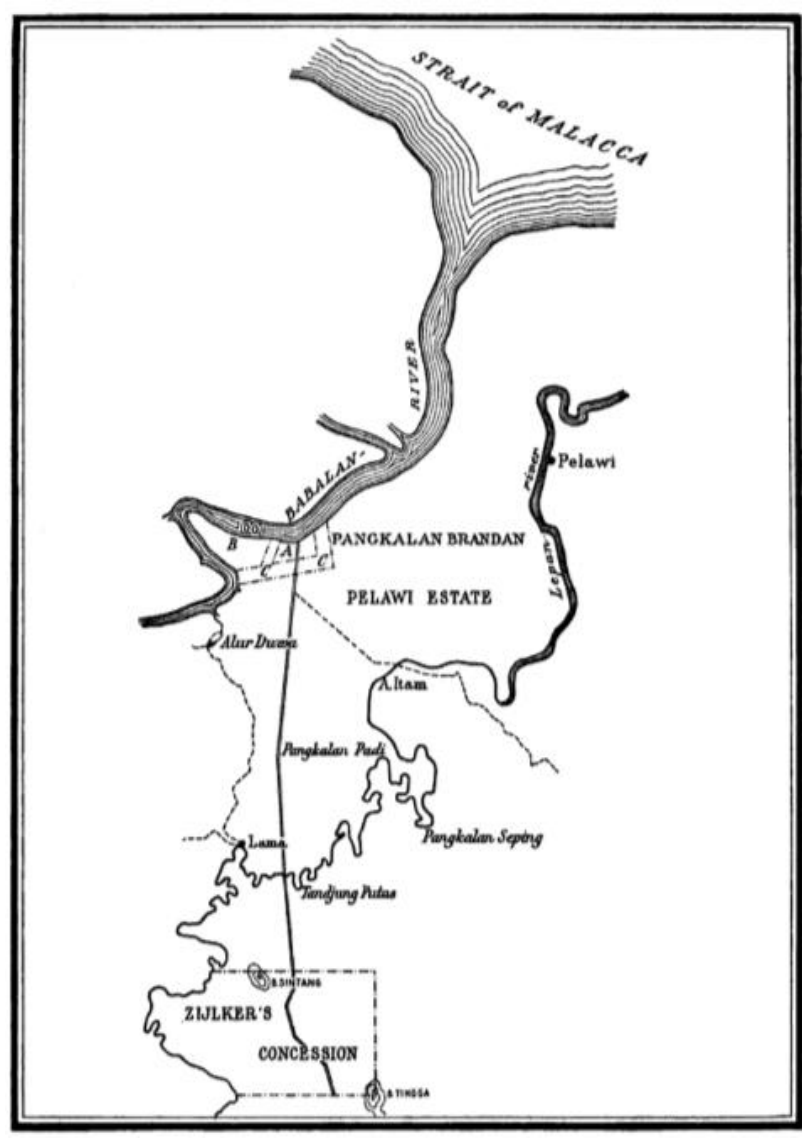

Gambar 1. Peta Pangkalan Brandan dan Konsesi Minyak Bumi Ziljker. Sumber: F.C. Gerretson, History of the Royal Dutch, Volume 2. Leiden: E.J. Brill, 1958.

Orang Melayu asal Negeri Perlis yang pertama kali bermigrasi ke Desa Perlis adalah Haji Mat Thaif. Alasan kepindahannya ke Kampung Tanjung Balai didorong oleh kepentingan bisnis, yaitu supaya lebih mudah mengumpulkan 
hasil lada, beras maupun atap nipah untuk diperdagangkan. Namun, ada pendapat yang mengatakan bahwa Haji Mat Thaif diminta oleh Nyak Aris untuk menetap di kampungnya guna mengajarkan Agama Islam. Haji Mat Thaif kemudian menyusul keluarganya yang berada di Utan Aji, Negeri Perlis untuk turut bermigrasi ke Kampung Tanjung Balai. Adapun orang-orang pertama yang bermigrasi ke Kampung Tanjung Balai ialah ibunda Haji Mat Thaif yang bernama Safiah atau Piah, istrinya yang bernama Zubaeha atau Be'ah, dan enam anak Haji Mat Thaif. Anaknya yang pertama bernama Haji Jusu (Jusuf), kemudian Haji Abdullah (kembali ke Malaya), Hajjah Esah, Haji Ali, Man (Usman) Panjang, dan Umar (meninggal saat masih remaja). Selanjutnya, kakak tertua Haji Mat Thaif yang bernama Hajjah Maimunah beserta anak-anaknya, serta anak-anak dari adik Safiah yang bernama Nakhoda Kecik dari Pulau Penang turut pula bermigrasi ke Kampung Tanjung Balai. Nama anak-anak dari Nakhoda Kecik itu ialah Thalib, Taher, dan Said. Mereka berangkat dari Kuala Perlis menggunakan kapal layar menuju Kampung Tanjung Balai yang ada di kuala Sungai Babalan (Wawancara dengan Bapak Muhammad dan Arifin Ahmad, 11 dan 17 April 2018).

Mereka membuka pemukiman baru yang saat ini telah menjadi Pemakaman Umum Sri Menanti, letaknya sekitar 200 meter dari dermaga Desa Perlis dan tidak jauh dari tepi sungai (Wawancara dengan Bapak Muhammad, 17 April 2018). Pembukaan pemukiman awal di Desa Perlis berkisar tahun 1875. Penentuan tahun ini didasarkan pada peringatan 100 tahun beridirinya Desa Perlis yang diselenggarakan pada tahun 1975 oleh para keturunan Haji Mat Thaif. Namun, tahun 1885 kemungkinan bukanlah tahun awal kedatangan mereka, karena saat itu pemukiman telah berkembang di Kampung Perlis dan jumlah penduduknya meningkat. Mereka menamakan sendiri wilayah pemukimannya agar berbeda dengan pemukiman lain disekitarnya.
Kampung Tanjung Balai atau Kampung Perlis masuk wilayah otorita Kesultanan Langkat. Oleh karena itu, pada masa Sultan Abdul Aziz bertahta di Kesultanan Langkat, diutus Datuk Komdan Abdul Jalil Indera Wangsa dari Tanjung Pura sebagai Penghulu Balai di Kampung Perlis. Di bawah kesultanan dan asisten residen, struktur pemerintahan disebut luhak dan di bawah luhak disebut kejuruan dan distrik secara berjenjang disebut Penghulu Balai yang berada di kampung. Tugas penghulu di Kampung Perlis adalah sebagai perwakilan sultan dan mengutip upeti dari hasil alam dan perdagangan di Kampung Perlis untuk dikirim ke Tanjung Pura (Wawancara dengan Ruslan Adek, 18 April 2018). Setelah Datuk Komdan Jalil wafat pada tahun $1320 \mathrm{H}$ (1898 M), kedudukan Penghulu Kampung Perlis diteruskan kepada anak sulungnya yang bernama OK. Sahyan. Kepemimpinan Sahyan sebagai Penghulu Kampung Perlis berlangsung hingga masa revolusi sosial tahun 1946. Setelah itu, penghulu Kampung Perlis dijabat oleh Yahya yang merupakan keturunan pendatang dari Semenanjung Malaya (Wawancara dengan Ruslan Adek, 18 April 2018). Ketika Republik Indonesia telah berdiri, Kampung Perlis dalam perkembangannya dijadikan suatu desa administratif sendiri yang bernama Desa Perlis.

\section{Kehadiran Pendatang dan Interaksi Sosial}

1. Komunitas Cina

Orang-orang Cina telah lama hadir dalam panggung sejarah Sumatera. Sejak masa Sriwjaya hingga era kolonial, orang-orang Cina telah datang ataupun didatangkan dengan bermacam latar belakang. Anderson yang berkeliling ke wilayah-wilayah pantai timur pada tahun 1823 , melihat sedikit sekali orang Cina di Deli dan hampir tidak pernah melihat orang Cina di tempat-tempat lain (Reid, 2011: 194). Di era kolonial, tepatnya pada masa perkebunan tembakau Deli sedang giat-giatnya memperluas lahan, tuan-tuan kebun mempekerjakan buruh-buruh asal Cina dengan jumlah yang besar. Pemu- 
kiman mereka terkonsentrasi di bangsal-bangsal perkebunan yang disediakan oleh perusahaan perkebunan. Seorang bernama Nienhuys, perintis perkebunan tembakau di Deli, adalah tokoh yang pertama kali mendatangkan buruh-buruh asal Cina. Pada 1865, ia membawa 88 orang Cina dan 23 orang Melayu dari Penang sebagai buruh (Reid, 2011: 195).

Orang Cina adalah pendatang pertama yang menetap di Desa Perlis. Mereka adalah bekas buruh kontrak perkebunan. Dalam peraturan tentang kuli yang dibuat pemerintah kolonial Belanda, para pengusaha perkebunan atas permintaan yang bersangkutan wajib mengembalikan para buruh itu ke tempat-tempat asal mereka pada akhir masa kontrak (Pelzer, 1985: 84-85). Tetapi, banyak buruh yang lebih memilih untuk tetap tinggal di Sumatera Timur. Mereka keluar dari perkebunan dan bermukim di kampung-kampung sekitar perkebunan maupun kota-kota yang sedang berkembang. Orang Cina yang datang ke Desa Perlis adalah bekas buruh perkebunan dan pertambangan minyak yang ada di wilayah Langkat. Mereka menetap di Desa Perlis dengan menumpang pada tanah-tanah yang dimiliki oleh etnik Melayu.

Lokasi pemukiman etnik Cina di Desa Perlis terletak di Dusun II yang dikenal dengan nama "Tambang Cina". Untuk memenuhi kebutuhan spiritual, mereka mendirikan tempat peribadatan. Ada dua tempat ibadah yang mereka dirikan. Tempat ibadah yang pertama berada di Dusun I yang disebut dengan Pekong Cina, sayangnya saat ini bangunannya sudah tidak ada. Tempat ibadah orang Cina yang terbesar di Kampung Perlis terdapat di Tambang Cina, tetapi saat ini sudah beralih fungsi menjadi tempat tinggal.

Pada tahun 1998, sudah tidak ada lagi orang Cina yang menetap di Desa Perlis. Hasil dari usaha beternak mendorong mereka untuk pindah ke perkotaan, seperti Pangkalan Brandan dan Medan. Mereka menjual rumah dan tanahnya di Desa Perlis kepada penduduk setempat, termasuk kelenteng Tambang Cina.
2. Pendatang Jawa

Kedatangan orang Jawa ke Desa Perlis mulai terjadi pada tahun 1950 hingga 1970. Pendatang awal adalah bekas buruh kontrak di perkebunanperkebunan yang berdekatan dengan Desa Perlis, seperti perkebunan Gebang, Securai dan Pelawi. Saat berpindah ke Desa Perlis, beberapa dari mereka awalnya bekerja sebagai buruh upahan di peternakan milik orang Cina. Kemudian pendatang-pendatang Jawa membuka lahan baru di atas tanah yang dipinjam dari penduduk setempat. Pelaku pembukaan lahan tersebut masih diingat oleh masyarakat Desa Pelis. Mereka adalah Marlan, Panut, Paing, Sinto, dan Setu.

Pendatang Jawa lainnya adalah bekas romusa pada masa pendudukan Jepang. Sebagian besar dari mereka berasal dari solo. Beberapa di antara bernama Slamet, Syarif (kembali ke Jawa), Kardi (pindah ke Langsa), Usman Wongso dan Simun (Wawancara dengan Ibrahim, 23 April 2018). Mereka direkrut menjadi romusa oleh Jepang dengan cara dibujuk atau dirawu melalui tipu muslihat (Isnaeni \& Apid, 2008: 97100). Mereka dijanjikan akan disekolahkan di Sumatera, tetapi ternyata dipekerjakan secara paksa untuk membangun pelabuhan dan benteng pertahanan Jepang di kuala Sungai Babalan (Wawancara dengan Ibrahim, 23 April 2018).

Para pendatang Jawa di Desa Perlis awalnya menumpang di lahan penduduk setempat yang lokasinya jauh dari pemukiman. Mereka membuka hutan untuk dijadikan tempat tinggal dan juga lahan pertanian. Kondisi tanah di lahan yang mereka buka cukup layak untuk dikembangkan sebagai areal pertanian, karena air asin bisa dihalau dengan membangun tanggul. Pertanian yang dikembangkan oleh pendatang Jawa adalah budidaya padi. Mereka menggunakan sawah tadah hujan, karena di daerah ini tidak ada irigasi. Meristis usaha ini tidaklah mudah, karena air asin terkadang masuk dan menggenangi areal sawah yang mengakibatkan padi gagal panen. Setelah tanggul dibangun atas kerja gotong royong penduduk Desa Perlis, budidaya padi semakin berkembang. Keberhasilan 
budidaya padi yang dilakukan pendatang Jawa menarik keinginan nelayan Melayu untuk mencoba usaha yang sama. Beberapa nelayan Melayu meninggalkan perahunya dan memilih untuk menjadi petani (Wawancara dengan Bapak Rasman, 23 April 2018).

Kedatangan orang Jawa terakhir dalam jumlah kecil ke Desa Perlis terjadi hingga tahun 1970. Kepindahan mereka ke Desa Perlis juga terkait dengan hubungan kekerabatan. Areal persawahan terus bertambah luas seiring kedatangan orang-orang Jawa, sehingga Desa Perlis tidak hanya terkenal dengan hasil tangkapan ikan dan telur bebek, tetapi juga sebagai penghasil padi. Lokasi pemukiman yang dibuka oleh pendatang Jawa dijadikan dusun tersendiri oleh pemerintah Desa Perlis, yaitu Dusun VI Kenanga. Namun, sebelum nama dusun tersebut ditetapkan, nama Kampung Jawa lebih dahulu populer di kalangan penduduk Desa Perlis hingga sekarang.

\section{Pendatang Aceh}

Pendatang asal Aceh di Desa Perlis adalah pemuda-pemuda perantau yang berasal dari Meureudu. Mereka berpindah ke Desa Pelis pada tahun 1960-an. Tujuan mereka merantau ke Desa Perlis untuk menjadi nelayan. Beberapa dari mereka merupakan nelayan ulung. Keahlian itu membuat mereka dijadikan sebagai pawang (nakhoda) kapal.

Sebagian pendatang asal Aceh menikah dengan perempuan-perempuan setempat. Dari pernikahan itu, ikatan mereka dengan Desa Perlis semakin kuat sehingga mereka tidak lagi tertarik untuk kembali ke kampung halamannya. Keengganan pulang ke kampung halaman juga dipengaruhi oleh sumber penghasilan yang sangat mudah mereka dapatkan karena tempatnya tidak jauh dari pemukiman mereka (Wawancara Asnawi, 24 April 2018).

Pendatang asal Aceh juga ikut membuka hutan untuk dijadikan pemukiman dan lahan pertanian. Keterlibatan mereka ini tidak bersamaan dengan pendatang Jawa yang menjadi perintis budidaya padi di Desa Perlis. Pendatang Jawa dan pendatang Aceh membuka petak-petak sawah yang sangat luas. Kegiatan pertanian di Desa Perlis semakin menggeliat. Mereka tidak hanya menanam padi, tetapi juga tanaman palawija dan sayur-sayuran. Hasil pertanian dan perikanan di Desa Perlis ternyata mampu memenuhi kebutuhan penduduknya.

\section{Pendatang lainnya}

Pendatang dari kelompok etnik lain tidak terlalu banyak jumlahnya. Mereka adalah orang Banjar, Minangkabau dan Mandailing. Sebagian dari mereka bekerja sebagai nelayan atau buruh nelayan. Selain itu, ada pula dari mereka yang bekerja sebagai pegawai negeri dan pekerja upahan di peternakan bebek milik orang Cina.

Kebanyakan orang Banjar, Mandailing dan Minangkabau menikah dengan orang Melayu. Ketiga etnik pendatang ini hidup membaur dengan orang Melayu. Bahkan bahasa yang mereka gunakan sehari-hari adalah bahasa Melayu. Berbeda dengan pendatang Cina, Jawa dan Aceh yang cenderung membuka pemukiman sendiri, terpisah dengan pemukiman orang Melayu. Hal ini dikarenakan adanya perbedaan mata pencaharian. Orang Melayu yang bekerja sebagai nelayan mendirikan rumah di tepi sungai, sedangkan orang Cina, Jawa dan Aceh yang bekerja sebagai peternak dan petani mendirikan rumah di lokasi yang sedikit menjauh dari tepi sungai karena mereka membutuhkan lahan yang luas.

Kehidupan antar etnik sangat rukun dan damai, tidak pernah terdengar adanya konflik di antara mereka. Toleransi beragama juga terjalin baik di desa ini. Agama-agama yang dianut oleh penduduk desa adalah Islam dan Buddha. Namun, saat ini agama Islam menjadi agama yang dianut oleh seluruh masyarakat Desa Perlis karena komunitas Cina telah meninggalkan desa itu. 


\section{Kehidupan Sosial-Ekonomi}

Rata-rata keluarga di Desa Perlis memiliki tanggungan 4-5 orang. Tingkat pendidikan di desa ini didominasi oleh lulusan SLTP dengan jumlah 380 jiwa. Jumlah penduduk yang putus sekolah sebanyak 3.014 jiwa. Namun, angka putus sekolah itu dihitung secara umum untuk seluruh kalangan usia. Penduduk yang sama sekali tidak pernah bersekolah sangat kecil jumlahnya, hanya 30 orang. Anak-anak yang sedang sekolah mulai dari jenjang SD hingga SMA berjumlah 1.197 siswa. Rumah-rumah penduduk masih didominasi oleh material kayu, sedikit sekali rumah penduduk yang menggunakan bata atau beton sebagai material utama. Keadaan lingkungan sekitar rumah penduduk kurang bersih. Banyak sampah kiriman dari Kota Pangkalan Brandan yang berserakan di sekitar lingkungan pemukiman akibat dibawa oleh arus pasang, khususnya di rumah-rumah yang didirikan di pinggiran sungai. Sanitasi penduduk cukup baik karena mereka telah membangun WC di dalam rumah dan memiliki septictank sendiri.

Dari segi mata pencaharian, ada tiga jenis pekerjaan dominan yang digeluti masyarakat Desa Perlis, yaitu nelayan, petani, pedagang kecil dan pekerja sektor jasa.

\section{Nelayan}

Aktivitas menangkap ikan merupakan mata pencarian yang sangat tua (Koentjaraningrat, 2009: 285). Di Desa Perlis, pekerjaan sebagai nelayan merupakan matapencarian dominan dan telah berlangsung sejak pertama kali penghijrah masuk ke Desa Perlis sekarang. Berdasar data Profil Desa Perlis (2017), diperoleh jumlah penduduk desa yang bekerja sebagai nelayan sebanyak 550 orang dan semuanya adalah lakilaki. Kehidupan masyarakat nelayan adalah keadaan nyata yang dapat diungkapkan melalui usaha mereka yang dipengaruhi oleh musim penangkapan ikan, kondisi alam tidak menunjang, terbatasnya modal, dan tingkat pendidikan yang rendah sehingga mengakibatkan keadaan sosial ekonomi lemah (Watung, dkk., 2013: 9). Nelayan Desa Perlis masih dikategorikan sebagai nelayan kecil dengan jaring sebagai alat tangkap utama mereka. Jenis tangkapan andalan mereka adalah ikan bawal dan udang. Lokasi penangkapan mereka tidak jauh dari muara Sungai Babalan, sekitar 12-15 mil dari bibir pantai atau sampai tidak kelihatan daratan. Ukuran perahu mereka bervariasi, umumnya ada dua jenis ukuran perahu yang dimiliki para nelayan yaitu panjang 7-12 meter.

Tidak semua nelayan memiliki perahu sendiri, sedikit nelayan yang memiliki perahu sendiri. Banyak dari para nelayan tersebut sebenarnya adalah buruh nelayan, yakni ikut bekerja kepada nelayan yang memiliki perahu dan alat tangkap sendiri. Buruh-buruh nelayan tersebut umumnya masih berusia muda berkisar antara usia 18-30 tahun. Akan tetapi, tidak jarang ditemui buruh nelayan yang berusia di atas 30-40 tahun. Upah para buruh nelayan ini tergantung dari hasil tangkapan, untung yang besar akan berdampak pada banyaknya nominal upah yang akan para buruh terima. Umumnya mereka mendapatkan upah Rp. 75.000 - Rp. 120.000 tiap kali pergi menangkap ikan. Mereka akan berangkat pada pagi hari dan pulang di sore hari atau pergi di malam hari dan pulang di pagi hari. Upah mereka sangat kecil, jarang mendapatkan upah pada nominal Rp. 100.000 - Rp. 150.000 (Wawancara dengan Husin, 26 April 2018).

\section{Petani}

Usaha pertanian yang lebih luas dan menjadi sumber penghidupan utama mulai dikerjakan oleh Pendatang Jawa. Mereka menumpang tanah kepada penduduk setempat yang masih merupakan hutan belukar. Sebelum kedatangan pendatang Jawa, hanya sebagian penduduk yang mengusahakan areal pertanian. Pembukaan areal persawahan pertama di Desa Perlis bersamaan dengan kedatangan Pendatang Jawa pada tahun 1960-an. Petak-petak sawah baru terus bertambah seiring kehadiran Pendatang Aceh. Kedua 
kelompok Pendatang dari etnis berbeda ini secara bergotong royong bekerja membuka lahan persawahan baru. Kesulitan mereka hadapi ketika air pasang masuk menggenangi areal sawah. Benteng-benteng timbunan tanah pun dibangun untuk mencegah air asin masuk ketika pertanian sawah memiliki daya tarik lebih bagi para pendatang. Dengan didirikannya tanggultanggul tersebut, produksi beras yang dihasilkanpun cukup memuaskan (Wawancara dengan Asnawi, 24 April 2018).

Hamparan luas sawah yang terbentang di Kampung Jawa dan Kampung Aceh bertahan hingga akhir tahun 2000. Selama kurang lebih 30 tahun sejak dibukanya Kampung Jawa dan Kampung Aceh yang ikut menjadi penanda dibukanya lahan pertanian sawah di Desa Perlis, yakni pada tahun 1960-an mulai beralih ditanami pohon kelapa sawit. Proses konversi lahan sawah menjadi perkebunan kelapa sawit rakyat ini terjadi perlahan-lahan yang dirintis oleh seorang petani yang kemudian diikuti oleh petani-petani lainnya. Penyebab pengalihan lahan sawah menjadi perkebunan kelapa sawit disebabkan antara lain oleh gangguan hama dan masuknya air asin yang sering mengakibatkan gagal panen. Hingga tahun 2004, sawah terakhir di Desa Perlis beralih ditanami kelapa sawit. Sawah-sawah di Kampung Jawa menjadi areal perkebunan kelapa sawit rakyat pertama di Desa Perlis, kemudian menyusul Kampung Aceh. Seluruh sawah-sawah di Desa Perlis telah dijadikan lahan kelapa sawit, kecuali beberapa lahan di Kampung Jawa yang ditanami sayurmayur dan tanaman pohon buah-buahan. Begitupula di Kampung Aceh, ada beberapa lahan yang ditanami pohon karet dan pohon mangga. Namun, kelapa sawit tetap mendominasi komoditi pertanian di Desa Perlis.

\section{Pedagang Kecil dan Pekerja Sektor Jasa}

Pedagang kecil menjadi sektor ekonomi yang dipilih masyarakat Desa Perlis. Ada juga nelayan-nelayan yang telah berhenti dari pekerjaannya karena faktor usia, memilih untuk membuka usaha warung kopi dan kedai kelontong. Warung makan atau warung kopi menjadi tempat-tempat pertemuan kaum pria untuk bersosialisasi. Mereka biasa berinteraksi di warung kopi sesudah pulang dari melaut atau hanya sekedar untuk bercengkrama. Dapat dikatakan warung kopi atau warung makan adalah pusat perkumpulan kaum pria di Desa Perlis. Pedagang keliling di Desa Perlis menawarkan kudapan, kue-kue, jajanan, dan juga bahan pangan seperti sayur-sayuran, buahbuahan, daging ayam, bumbu masakan dan lainlain. Mereka menggunakan gerobak, sepeda, atau kereta sorong untuk menjajakan dagangannya. Jalanan Desa Perlis selalu ramai dilintasi oleh pedagang-pedagang keliling ini, khususnya di sore hari. Selain pedagang keliling yang merupakan penduduk setempat, pedagang dari luar desa juga banyak datang untuk berdagang di desa ini. Produk yang ditawarkan oleh pedagang-pedagang keliling dari luar desa tidak jauh berbeda dengan pedagang dari Desa Perlis. Beberapa ada pula pedagang keliling yang menjual sandal, sepatu, pakaian dan produk-produk kecantikan.

Penduduk Desa Perlis ada yang bergerak di sektor jasa dan pelayanan umum. Pekerja sektor jasa di desa ini masih dalam ruang lingkup yang kecil seperti tukang cuci, tukang cukur, tukang listrik dan tukang jahit. Tukang cuci biasa mencuci pakaian pelanggannya di bor-boran. Bor-boran dalam bahasa penduduk setempat adalah tempat pemandian umum. Sumber air di tempat pemandian ini berasal dari pengeboran yang dibuat oleh Kesultanan Langkat pada tahun 1925. Sampai hari ini, air dari sumur bor di tempat ini terus mengalirkan air yang menjadi sumber air utama penduduk Desa Perlis. Kebutuhan air bersih dan layak konsumsi menjadi masalah yang dihadapi oleh penduduk Desa Perlis. Sumur bor ini telah menjadi solusi sejak masa sebelum kemerdekaan hingga hari ini. Air-air diambil secara gratis oleh penduduk. Meskipun telah ada sumur-sumur bor yang digali Pemerintah Desa atau milik per- 
orangan, air yang keluar dari bor-boran tetap dianggap sebagai air terbaik di Desa Perlis.

Pekerja sektor jasa yang cukup besar di Desa Perlis adalah jasa penyeberangan. Terdapat 32 penyedia jasa angkutan penyeberangan. Penyeberangan ini memanfaatkan sampan dayung yang disebut penduduk setempat dengan istilah "tambang". Orang yang bekerja sebagai pendayung sampan ini disebut sebagai "penarik tambang". Penarik tambang ini menggunakan sampan kecil dengan panjang 3 meter. Tidak semua sampan yang mereka gunakan adalah milik sendiri, ada beberapa penduduk yang menyewakan perahunya. Seluruh penarik tambang adalah pria, sedangkan perempuan bertindak sebagai penyewa sampan (Wawancara dengan Safril, 18 April 2018).

Para penarik tambang beraktivitas mulai dari pukul 06.00 hingga pukul 22.00 WIB. Di malam-malam tertentu, seperti malam rabu dan malam minggu, mereka bisa bekerja hingga pukul 23.00 WIB. Ongkos yang diterapkan untuk sekali penyeberangan sebesar Rp. 3000 per orang. Dalam satu hari mereka memperoleh penghasilan antara Rp. 50.000 hingga Rp. 60.000 bila mulai beraktivitas dari pagi sampai sore hari, dengan total penyeberangan 10 kali bolak-balik dari dermaga Perlis ke dermaga Pangkalan Berandan atau sebaliknya. Bila mereka bekerja hingga malam dan penumpang sedang ramai, mereka bisa meraup keuntungan hingga Rp. 100.000 (Wawancara dengan Janil, 18 April 2018).

\section{Perubahan Sosial-Budaya}

Masyarakat selalu bergerak, berkembang dan berubah, mereka tidak pernah diam. Dinamika masyarakat ini terjadi bisa karena faktor internal yang inheren melekat dalam "diri" masyarakat itu sendiri, dan bisa juga karena faktor lingkungan eksternal (Narwoko \& Suyanto, 2013: 378). Perubahan sosial budaya merupakan sebuah gejala berubahnya struktur sosial dan pola budaya dalam suatu masyarakat. Perubahan ini merupakan gejala umum yang terjadi sepan- jang masa dalam setiap masyarakat karena sifatnya yang dinamis, tidak statis. Perubahan sosial budaya terjadi karena beberapa faktor, Soekanto, (2014: 273:279) menjelaskan faktorfaktor penyebab perubahan sosial dan kebudayaan yang bersumber dari dalam masyarakat itu sendiri, antara lain: (1) bertambah dan berkurangnya penduduk; (2) penemuan-penemuan baru; (3) pertentangan (conflict) masyarakat; (4) terjadinya pemberontakan atau revolusi. Suatu perubahan sosial dan kebudayaan dapat pula bersumber pada sebab-sebab yang berasal dari luar masyarakat itu sendiri, antara lain: (1) sebab-sebab yang berasal dari lingkungan alam fisik yang ada di sekitar manusia; (2) peperangan; (3) pengaruh kebudayaan masyarakat lain (Soekanto, 2014: 279-280).

Desa Perlis sebagai suatu organisasi sosial yang terdiri dari penduduk dengan latar belakang etnik yang beragam tentu mengalami dinamika perubahan dalam kehidupan bermasyarakat. Kemajuan zaman telah menggeser pola pikir tradisional ke modern yang berakibat beberapa tradisi dianggap tidak relevan sehingga tidak dilestarikan. Peningkatan pemahaman agama juga menjadi faktor perubahan sosial budaya. Tradisi yang dianggap bertentangan dengan hukum-hukum agama mau tidak mau ditinggalkan dan hilang dikemudian hari.

Upacara atau ritual Jamu Laut merupakan tradisi yang berlaku pada masyarakat nelayan. Ritual ini dilaksanakan pada masa sulit mendapatkan tangkapan ikan. Untuk melaksanakan upacara ini, masyarakat akan menyelenggarakan hajatan dengan membuat beragam makanan, kue-kue, nasi beserta lauk-pauknya, disertai bermacam warna bunga. Upacara ini dipimpin oleh seorang Pamong Laut yang berasal dari nelayan yang dituakan oleh penduduk setempat. Tradisi tolak bala ini sudah tidak dijalankan lagi sejak tahun 1975. Hal tersebut tidak terlepas dari peranan seorang tokoh agama yang berusaha memberikan pemahaman kepada pimpinan desa bahwa tradisi ini menyalahi hukum-hukum Islam, ditambah mayoritas penduduk Desa Perlis 
beragama Islam. Upacara itu dianggap mubazir karena telah membuang makanan ke dasar laut dan perbuatan itu dianggap menyekutukan Tuhan (sirik). Lambat laun, pimpinan desa dan adat meninggalkan tradisi Jamu Laut ini. Perubahan ini terjadi dari dalam masyarakat Desa Perlis dengan adanya keterlibatan Tokoh agama yang berpengaruh, sehingga upacara ini tidak dikerjakan (Wawancara dengan Bapak Muhammad, 17 April 2018).

Selanjutnya tradisi Kenduri Sawah yang dijalankan oleh penduduk di Kampung Jawa yang dominan bekerja sebagai petani. Mereka melaksanakan tradisi Kenduri Sawah sebelum memulai masa tanam padi. Tradisi ini dikerjakan dan dihadiri oleh seluruh keluarga petani yang memiliki sawah. Dalam pelaksanaan upacara ini setiap keluarga diwajibkan membawa bahan makanan seperti daging atau ayam beserta bumbunya untuk dimasak bersama. Tiap orang membawa nasi masing-masing untuk dimakan dengan daging yang dimasak bersama tadi. Upacara ini dipimpin oleh Tokoh yang dituakan dikalangan petani untuk membaca doa-doa memohon dihindarkan dari kesulitan selama masa tanam hingga panen. Setelah selesai membaca doa, mereka pun menyantap makanan yang telah disediakan bersama-sama (Wawancara dengan Bapak Rasman, 23 April 2018). Tradisi ini sudah tidak dikerjakan oleh penduduk sejak beralihnya persawahan menjadi perkebunan kelapa sawit. Hilangnya tradisi ini bukan karena masyarakat menganggapnya bertentangan dengan norma agama ataupun dengan nilai-nilai lainnya. Akan tetapi, perubahan ini dipicu oleh perubahan dari luar masyarakat, tepatnya karena pengaruh lingkungan alam. Air pasang yang masuk menggenangi sawah dan gangguan hama telah menghambat usaha pertanian mereka. Akibatnya, beberapa petani memutuskan mengubah sawah mereka menjadi perkebunan kelapa sawit. Tindakan para perintis perkebunan kelapa sawit rakyat di Desa Perlis itu diikuti oleh petani-petani lainnya, sehingga seluruh sawah di Desa Perlis ditanami kelapa sawit.
Tradisi yang masih berlaku di Desa Perlis yaitu upacara pernikahan dan upacara ayun anak. Upacara pernikahan yang dijalankan sesuai ketentuan adat pun banyak yang tidak dikerjakan. Hanya tradisi berinai dan tepung tawar yang masih dikerjakan penduduk. Alasan tidak sesuainya lagi ketentuan adat dalam upacara pernikahan ini bukan dikarenakan ketidakmampuan finansial. Akan tetapi, karena ketidaktahuan akibat tidak terjaganya tradisi dengan baik. Namun, ada satu fakta unik yang terjadi dalam upacara pernikahan pada penduduk Desa Perlis khususnya penduduk etnis Jawa.

Ada suatu proses gerak budaya antara budaya Jawa dengan Melayu dalam pelaksanaan upacara perkawinan. Akulturasi yang terjadi antara kedua budaya itu dapat dilihat pada saat sebelum perkawinan, menjelang dan saat proses kepanggihan (upacara pertemuan), sehingga upacara perkawinan pada masyarakat Jawa tidak lagi murni (Nurjannah \& Ayu, 2016: 123). Adapun corak akulturasi antara budaya Jawa dan Melayu Perlis dalam pelaksanaan upacara perkawinan masyarakat Jawa dapat dilihat antara lain pada saat antaran, malam berinai, bersanding satu, tepung tawar, marhaban dan balai. Asal terjadinya perpaduan dua budaya ini bermula dari pernikahan antara seorang Jawa dengan perempuan Melayu Perlis. Kemudian, lambat laun upacara pernikahan yang bercampur antara dua budaya ini dilaksanakan penduduk etnis Jawa. Terlebih, bila itu adalah pernikahan antara pria etnis Jawa dengan perempuan Melayu Perlis.

\section{SIMPULAN}

Desa Perlis berkembang dari suatu pemukiman lama yang bernama Kampung Tanjung Balai yang dibuka oleh pelarian politik Tamiang sebelum tahun 1823. Kehadiran perantau dari Negeri Perli, Semenanjung Malaya membuka pemukiman baru disebelah Kampung Tanjung Balai dengan nama Kampung Perlis pada tahun 1875. Kampung Perlis yang awalnya ditinggali oleh nelayan-nelayan Melayu terus berkembang 
seiring dengan kedatangan pendatang Cina pada tahun 1930-1940-an, kemudian pendatang Jawa dan Aceh pasca-proklamasi kemerdekaan, tepatnya tahun 1950-1960-an. Kehadiran pendatang tersebut menimbulkan perkembangan ekonomi dengan munculnya mata pencaharian baru, seperti pertanian dan peternakan. Selain itu, kontak budaya di antara beragam etnik memunculkan perubahan-perubahan dalam struktur budaya setempat, tetapi perubahan itu tidak signifikan.

Perubahan sosial-budaya terjadi akibat pemahaman agama dan peralihan komoditi tanaman, seperti ritual Jamu Laut dan Kenduri Sawah yang ditinggalkan. Akulturasi yang dominan dibentuk melalui garis perkawinan menghasilkan identitas baru bagi penduduk Desa Perlis, namun berimplikasi pula pada hilangnya identitas asli dengan tidak lestarinya kebudayaan asli, seperti adat pernikahan. Nilai-nilai budaya juga banyak yang hilang disebabkan pewarisan yang tidak optimal oleh generasi pendahulu. Kemajuan zaman dan kemiskinan mempengaruhi pula nilai-nilai keadaban, khususnya bagi generasi muda. Kesadaran pendidikan pada masyarakat sudah mencapai tahap yang baik, meskipun harus dihadapkan pada permasalahan ekonomi.

\section{REFERENSI}

Anderson, J. (1971). Mission to the East Coast of Sumatra in 1823. Kuala Lumpur: Oxford University Press.

Asnan, G. (2016). Sungai dan Sejarah Sumatera. Yogyakarta: Ombak.

BPS Kabupaten Langkat. (2017a). Brandan Barat dalam Angka 2017. Langkat: BPS Kabu-paten Langkat.

BPS Kabupaten Langkat. (2017b). Langkat dalam Angka 2017. Langkat: BPS Kabupaten Langkat.
Daryono, H. dkk., (2013). Dari Pangkalan Brandan Migas Indonesia Mendunia: Trans-formasi ke Non Migas di Pangkalan Brandan Suatu Keniscayaan. Jakarta: Petrominer.

Gerretson, F. C. (1958). History of the Royal Dutch, Volume 2. Leiden: E.J. Brill.

Isnaeni, H.F. \& Apid (2008). Romusa: Sejarah yang Terlupakan. Yogyakarta: Ombak.

Kantor Desa Perlis. (2017). Profil Desa Perlis 2017. Langkat: Tanpa penerbit.

Koentjaraningrat. (2009). Pengantar Ilmu Antropologi. Jakarta: Rineka Cipta.

Koestoro, L.P., Purnawibowo, S. \& Oetomo, R.W. (2016). Dinamika Aktivitas Kemaritiman di Pulau Kampai, Kota Cina dan Kota Rantang, Sumatera Utara. Jurnal SBA, 19(2), 96-109.

Narwoko, J. \& Suyanto, B. (2013). Sosiologi: Teks Pengantar \& Terapan. Jakarta: Penerbit Prenada Media Grup.

Nurjannah \& Ayu, G.A. (2016). Akulturasi Budaya pada Upacara Perkawinan Masyarakat Jawa Desa Perlis Kecamatan Brandan Barat. Anthropos: Jurnal Antropologi Sosial Dan Budaya, 2(2), 121-129.

Pelzer, K. J. (1985). Toean Keboen dan Petani: Politik Kolonial dan Perjuangan Agraria di Sumatra Timur 1863-1947. Jakarta: Sinar Harapan.

Reid, A. (2007). Asal Mula Konflik Aceh: Perebutan Pantai Timur Sumatera. Jakarta: Yayasan Pustaka Obor Indonesia.

Reid, A. (2011). Menuju Sejarah Sumatera: Antara Indonesia dan Dunia. Jakarta: Yayasan Pustaka Obor Indonesia.

Sjamsuddin, H. (2012). Metodologi Sejarah. Yogyakarta: Ombak.

Soekanto, S. \& Sulistyawati, B. (2014). Sosiologi: Suatu Pengantar. Jakarta: Rajawali Press. 
Watung, N., Dien, C. \& Kotambunan, O. (2013). Karakteristik Sosial Ekonomi Masyarakat Nelayan di Desa Lopana, Kecamatan Amurang Timur, Provinsi Sulawesi Utara. Jurnal Akulturasi, 1(2), 103-108.

Wawancara dengan Arifin Ahmad di Desa Perlis, 11 April 2018.

Wawancara dengan Asnawi di Kampung Aceh (Desa Pelis), 24 April 2018.

Wawancara dengan Bapak Muhammad di Desa Perlis, 17 April 2018.

Wawancara dengan Bapak Rasman di Kampung Jawa (Desa Perlis), 23 April 2018.

Wawancara dengan Husin di Desa Perlis, 26 April 2018.

Wawancara dengan Ibrahim di Kampung Jawa (Desa Perlis), 23 April 2018.

Wawancara dengan Janil di Desa Perlis, 18 April 2018.

Wawancara dengan Ruslan Adek di Desa Perlis, 18 April 2018.

Wawancara dengan Safril di Desa Perlis, 18 April 2018. 